\title{
Preservation of Javanese Cultural Values Through Conservation Education Course (A Study on the Students of Faculty of Education Passed Conservation Education Course)
}

\author{
Ilyas $^{1}$, Sawa Suryana ${ }^{2}$, Mualim ${ }^{3}$ \\ Ilyas.pnf@mail.unnes.ac.id ${ }^{1}$ \\ Universitas Negeri Semarang ${ }^{1}$
}

\begin{abstract}
This study aims at investigating internalization of Javanese cultural values, acculturation strategy, and critical role of educational institution in maintaining and preserving Javanese cultural values. The subject of this study consisted of six students of Universitas Negeri Semarang who have passed conservation education course. This study used qualitative approach conducted through interview and observation. The result of this study showed that the students still maintain, preserve, and utilize Javanese cultural values. They use integration as acculturation strategy between Javanese and global values. In addition, the result amplifies the evaluation that conservation education in Universitas Negeri Semarang generally can be considered successful despite shortage in several aspects.
\end{abstract}

Keywords: conservation education, acculturation strategy, integration, Javanese culture, global culture

\section{Introduction}

Acculturation between culture and its dynamics is inevitable. The acculturation process prompts integration, assimilation, separation, or isolation (Berry, Poortiga, Segall, and Marshall, 2002) ${ }^{1}$. Similarly, in the context of Javanese culture, acculturation between Javanese culture and foreign one cannot be avoided. And it provokes impacts on every culture.

Modern culture wave with its industrial revolution becomes main color in global culture. The cultural movement develops beyond continents - from Europe-America to African and Asian countries, assimilating different culture. The movement is then widely known as globalization. In this context, global culture intersects national culture and wields its influence in Indonesia, especially in Java.

In the Javanese context, modern cultural influence can be easily found. Javanese people are nowadays familiar with modern technology. Moreover, modern science is also taught in educational institution, especially university. English as international language is also widely

Berry, J. W., \& Dasen, Y. H. P. marshall H. S. P. R. (2002). Cross-cultural psychology: Research and applications. In Journal of Social and Evolutionary Systems (Second Ed.). (2002). 
taught in classroom and mastered by Javanese people (Zentz, 2015) ${ }^{2}$. A large number of expatriates can also be found in Indonesia, particularly in big cities and provinces in Indonesia such as Bali. It shows that there is integration between Javanese culture and modern one. If it does not happen, it seems impossible to find Wayang (traditional puppet) in animated version (Prasetryo and Alamin, 2018) ${ }^{3}$, Javanese-European architecture in Pura Mangkunegara (Pebrianti, 2019) ${ }^{4}$, or Tayub dance as a part of tourism industry in Indonesia (Noordiana Juwariyah and Inda, 2017) 5 .

The reactions commonly emerge in the area of value differences between modern and local culture which is inherited from one generation to another and becomes main part of Javanese culture - values such as tolerance, friendship, mutual cooperation, and their various derivative practices in social context, (Jandra, Djamil, Salamon, Ansyory, Zein, 20156; Affan dan Maksum, 2016)7. In Javanese culture, for instance, attitude (unggah - ungguh) in language use has central cultural role. For Javanese people it is not ethical to speak Ngoko Javanese (lesspolite variety of language) to the older or respected people. Kromo madyo or kromo inggil (more polite variety of language) is considered more ethical and aesthetic instead.

In modern perspective, different use of language variety for people of different ages is often regarded as feudalism practice (Izzah and Salikin, 2016) ${ }^{8}$, and it is due to different social classes between the communicants and communicators (Winarti, 2018) ${ }^{9}$. In this point, assimilation between two cultures is likely to occur because of the differences. In Javanese culture, the use of ngoko, kromo, madyo, and kromo inggil is not considered as feudalism practice, yet it shows attitude of Javanese people to respect to the older or respected ones (Fernandez, 2008) ${ }^{10}$.

The phenomenon of cultural assimilation is generally experienced by young generation (late adolescence and early adulthood). Young generations, who are on average 18-22 (late adolescence), are generally students. Thus, the phases of internalizing the values of local culture also become the campus' responsibility as a place to study (besides family and society of course)

2 Zentz, L. 'Is English also the place where I belong?': linguistic biographies and expanding communicative repertoires in Central Java. International Journal of Multilingualism, 12(1), pp. 68-92. (2014).

${ }^{3}$ Prasetyo, D., \& Alamin, R. Y. Pemodelan Karakter Animasi Wayang Orang Berbasis Motion Capture. Idea Journal Desain, 16(2), 30. (2018).

${ }^{4}$ Pebriyanti, E. Akulturasi Kebudayaan Eropa Jawa pada Arsitektur Pura Mangkunegaran Sebagai Pengembangan Materi Sejarah Kebudayaan (Universitas Sebelas Maret). (2019).

${ }^{5}$ Noordiana, N., Juwariyah, A., \& Inda, F. The Impact of Tayub Exploitation on The Tradition and Life of Javanese Society. Harmonia: Journal of Arts Research and Education, 16(2), pp. 133-142. (2016).

${ }^{6}$ Jandra, M., Djamil, A. S., Salamon, H., Ansyory, A., \& Zein, M. D. Identity and Culture Change of Javanese in Johor. UMRAN - International Journal of Islamic and Civilizational Studies (EISSN: 22898204), 3(3-1), pp. 1-9. (2016).

7 Affan, M. H., \& Maksum, H. Membangun Kembali Sikap Nasionalisme Bangsa Indonesia Dalam Menangkal Budaya Asing di Era Globalisasi. Pesona Dasar, 3(4), pp. 65-72. (2016).

${ }^{8}$ Izzah, L., \& Salikin, H. Feudal Culture in the Ijen Highlands' Poor Society. KARSA: Jurnal Sosial Dan Budaya Keislaman, 24(2), pp. 173-185. (2016).

${ }^{9}$ Winarti, O. Language Shift of Krama to Bahasa Indonesia among Javanese Youths and it's Relation to Parents' Social Class. Jurnal Studi Komunikasi (Indonesian Journal of Communications Studies), 2(3), pp. 290-300. (2018).

${ }^{10}$ Fernandez, I. Y. Kategori Dan Ekspresi Linguistik Dalam Bahasa Jawa Sebagai Cermin Kearifan Lokal Penuturnya: Kajian Etnolinguistik Pada Masyarakat Petani Dan Nelayan. Kajian Linguistik Dan Sastra, 20(2), pp. 166-177. (2008). 
(Ward and Geeraert, 2016) ${ }^{11}$. According to the writers' observations, several campuses have understood the negative potential of foreign cultures, and have prepared various strategies to 'secure' their students from these negative influences. In addition, it aims at equipping students with noble values of the archipelago's cultural heritage.

One of the universities that has such program is Universitas Negeri Semarang (UNNES). As a conservation university, UNNES has carried out various strategic steps to conserve noble values of Javanese culture in Tri Dharma of Higher Education. One form of this policy is to organize courses in character education and conservation education. In these courses all academic activities of UNNES must refer to the principles of conservation: protection, preservation and sustainable use. Outcome of the course, students are expected to be virtuous and noble persons, and be able to address the use of natural resources, art and cultural human resources wisely. However, the strategic point of concern for the writers is how the values of Javanese culture values is preserved by the students who have passed these courses. Ideally, students who have passed conservation education course have more experience on the cultural values of the archipelago's heritage than those who have not. However, it is empirically necessary to prove it further.

Based on the background above and considering the strategic and important location of the issue, the writers are interested in conducting research with the title 'Preservation of Javanese Cultural Values through Conservation Education Course (A Study on the Students of Faculty of Education who have Passed Conservation Education Course)

\section{Research Methodology}

This study used qualitative approach referring to research problems addressed in this study, which consist of efforts to preserve Javanese cultural values through conservation education course for students who have passed that course in the Faculty of Education, UNNES. The subjects of this study were 6 Javanese students of Faculty of Education UNNES, and they have passed conservation education course.

Since the point of this study is preserving Javanese cultural values, the data in this study was primary and secondary data. The primary data was obtained directly from the students of Faculty of Education who have passed conservation education course. The secondary data, meanwhile, was collected from literature review.

In order to get the answers on the preservation efforts of Javanese cultural values in the university, the qualitative data is proceeded into three stages: reduction, presentation, and drawing conclusion. Data analysis in this study is explained descriptively.

\section{Results and Discussion}

The interview with the subjects of this study shows the following results. Some values of Javanese culture preserved by the students who have passed conservation education course consist of belief, trust, hope, patience, and harmony. Javanese culture really maintains relationship with God. Beliefs are always passed down to grandchildren - the society believes

\footnotetext{
${ }^{11}$ Ward, C., \& Geeraert, N. Advancing acculturation theory and research: The acculturation process in its ecological context. Current Opinion in Psychology, 8(April), pp. 98-104. (2016).
} 
that everything depends on God's will. People as the servants must comply with God's commands. The most prominent attitude in values of Javanese culture is to maintain the trust of others, they maintain mutual trust in agreement, in campus life. From the observation result, it is showed that they maintain mutual trust both in small and big agreements. They believe that if they do not obey the agreement there will be bad consequences. All humans must have hopes, and dreams cannot be reached without effort. However, effort is not enough. Every action must be accompanied by prayer so that it can succeed. Actions also need to be accompanied by strong determination. With all of those, success can be easily achieved. The definition of patience in Javanese culture is described with three things, lilo, nrimo, patience. They accept what they get such as college problem, for example: getting low score. In terms of friendship on campus they can accept their friends even if they do not agree. It is showed by the way they still build good social relationship. In addition, they can accept any condition in the campus even though it bad thing happens. Then, they try to change from bad thing to good one. It was proved when they receive final score that possibly is out of expectation. Firstly, they feel hard to accept it, but slowly they can accept it. As they still learn, they frequently still have unstable emotions, but it seems normal. Every individual tries to maintain relationships with friends in the campus and boarding house. They can have a harmonious relationship when they are tied to a particular department or institution. It means the ability to align themselves is only at the stage when they are still in an institutional bond. Thus, harmonious relationship can only be achieved with a friend in one department and class. But the harmony can also be realized in a small or personal. They still maintain good relationship with friends even though they are not in the same department. They can understand different ethnics and religions.

There are also some efforts in preserving values of Javanese culture such as preserving, maintaining, and developing. Five out of six student who have passed conservation education course always maintain spiritual values by actively doing worship (compulsory prayers 5 times a day). The prayer is always done either in campus or boarding house. The interview with SS revealed that he does prayer because he wants to maintain relationship with God so that it remains interwoven. Because by maintaining relationship with God, his prayer will be granted. Four out of six research subjects always tried to practice the values of ritual worship. It can be seen in social relations every day when they always hold the trust that has been given from their peers. They also try to practice religious values to the most basic stage. Their family relationships are also intertwined. It is proved by getting to know each other's name and their address. Even they sometimes visit each other. This is done so that family relationship can be maintained. Four out of five research subjects develop values of Javanese culture by encouraging their classmates to pray, but, they do not force them. It is showed when they hear the prayer call. Within social relationship, they can help their friends when they face difficulties. They try to motivate them so that they can stay strong.

In globalization era, people can be unconsciously degraded if they are not careful. This does not only happen to general public but also to university, which is be able to produce a new generation that is more productive, innovative, creative. However, it sometimes fails to achieve that goal. We can see this failure when college people no longer understand and apply eastern culture, especially Javanese culture. From the results of observations for students who are still able to practice Javanese cultural values in their daily lives both on campus and off campus, they are more mature than others. This can be seen by the indication that they rarely leave compulsory worship, either prayer or fasting. If they are on campus, they will immediately carry out prayers and must be congregated if they hear prayer call. This means that even though they have not been monitored by their parents, they can still understand which ones are obligatory and which are not. Sometimes, students coming from a good family lose their control in the 
campus. They rarely do prayer, or even some do not want to pray because they are no longer under parents' control. Globalization as a cultural movement with a variety of features has assimilated various culture, including Javanese. The research subjects in this study also live and grow in the globalization era. As Javanese who live in the global era, all of the subjects showed positive attitudes towards globalization. These attitudes can be seen from the observation carried out by the researcher. Globalization products seem to have become part of the daily subject. They use smart phone, laptop, motorcycle, and other modern equipment, and most of which are imported products. They also study modern western sciences such as digital information systems, educational technology, English, and so on. In addition, the subjects of this study also like to wear jeans.

As part of a society that lives in a global era, it is impossible for the subjects to reject or even separate themselves from the influence of globalization. The assimilation between global and local culture is inevitable and will lead to massive acculturation processes. As Javanese ethnic who shows positive attitudes towards globalization, acculturation process occurs within each subject.

Based on the results of the study, it can be drawn understanding that the respondents still adhere to the values of Javanese culture. It can be seen from their belief in God Almighty, trusting and maintaining trust in others, relying on God, patience in facing difficulties, maintaining harmony horizontally (social, environmental) and vertical (spiritual). They also maintain, preserve, and develop the values of Javanese culture. The subjects of this study also preserve the values of Javanese culture, meaning that they keep these values from fading away by maintaining confidence in God Almighty and carrying out rituals of worship (personal dimensions). In terms of preserving the values, the subjects show efforts to maintain the values by establishing and maintaining friendship. The subjects also contribute to development of the values by helping to invite their friends to worship, to give enthusiasm, and to share. In addition, they are also actively involved in attending cultural seminars.

\section{Conclusions}

The results of this study lead to several conclusions as follows. Regarding the values of Javanese culture in the subjects of this study, the students still firmly hold the values of Javanese culture. The values of Javanese culture still hold by the students are belief in God, in the form of actively carrying out obligatory prayers and hard work. The attitudes of lilo and nrimo are still being hold. However, patience still needs to be improved. In terms of maintaining harmony relationships, it is still limited to the group's emotional. The efforts made by the students in preserving the values of Javanese culture are maintaining compulsory worship and trying to implement the values of Javanese culture in real life, gaining knowledge, understanding Javanese culture by coming to several cultural gathering and seminars. The values of Javanese culture make the students calmer and feel that they can be accepted when they interact with their surrounding (in campus or boarding house). Thus, they become dignified individuals.

The students apply integration as their cultural strategy. Integration refers to an integration between Javanese culture and global culture. Javanese culture is placed as a core culture in the form of unity of values of Javanese culture (conclusions point 1). Global culture is placed as a surface structure for example in the form of mastery of technology and fashion style. Such strategy can be understood because the subjects try to be adaptive to global challenges but at the same time try to maintain Javanese cultural identity and values within themselves. The strength 
of the subject in maintaining the values of Javanese culture is the result of character education and conservation education. However, the results of conservation education are far from complete. 


\section{References}

[1] Affan, M. H., \& Maksum, H. Membangun Kembali Sikap Nasionalisme Bangsa Indonesia Dalam Menangkal Budaya Asing di Era Globalisasi. Pesona Dasar, 3(4), pp. 65-72. (2016).

[2] Berry, J. W., \& Dasen, Y. H. P. marshall H. S. P. R. (2002). Cross-cultural psychology: Research and applications. In Journal of Social and Evolutionary Systems (Second Ed.). (2002).

[3] Fernandez, I. Y. Kategori Dan Ekspresi Linguistik Dalam Bahasa Jawa Sebagai Cermin Kearifan Lokal Penuturnya: Kajian Etnolinguistik Pada Masyarakat Petani Dan Nelayan. Kajian Linguistik Dan Sastra, 20(2), pp. 166-177. (2008).

[4] Izzah, L., \& Salikin, H. Feudal Culture in the Ijen Highlands' Poor Society. KARSA: Jurnal Sosial Dan Budaya Keislaman, 24(2), pp. 173-185. (2016).

[5] Jandra, M., Djamil, A. S., Salamon, H., Ansyory, A., \& Zein, M. D. Identity and Culture Change of Javanese in Johor. UMRAN - International Journal of Islamic and Civilizational Studies (EISSN: 2289-8204), 3(3-1), pp. 1-9. (2016).

[6] Noordiana, N., Juwariyah, A., \& Inda, F. The Impact of Tayub Exploitation on The Tradition and Life of Javanese Society. Harmonia: Journal of Arts Research and Education, 16(2), pp. 133-142. (2016).

[7] Pebriyanti, E. Akulturasi Kebudayaan Eropa Jawa pada Arsitektur Pura Mangkunegaran Sebagai Pengembangan Materi Sejarah Kebudayaan (Universitas Sebelas Maret). (2019).

[8] Prasetyo, D., \& Alamin, R. Y. Pemodelan Karakter Animasi Wayang Orang Berbasis Motion Capture. Idea Journal Desain, 16(2), 30. (2018).

[9] Ward, C., \& Geeraert, N. Advancing acculturation theory and research: The acculturation process in its ecological context. Current Opinion in Psychology, 8(April), pp. 98-104. (2016).

[10] Winarti, O. Language Shift of Krama to Bahasa Indonesia among Javanese Youths and it's Relation to Parents' Social Class. Jurnal Studi Komunikasi (Indonesian Journal of Communications Studies), 2(3), pp. 290-300. (2018).

[11] Zentz, L. 'Is English also the place where I belong?': linguistic biographies and expanding communicative repertoires in Central Java. International Journal of Multilingualism, 12(1), pp. 68-92. (2014). 